\title{
Research on Influence of Online Group-Buying Marketing on the Market
}

\author{
Yating Du, ${ }^{1, a}$ \\ ${ }^{1}$ Major of Marketing, Jiaxiang Foreign Languages School Attached Chengdu No.7 Middle School, Chengdu, \\ 610000, China
}

Key words:marketing; network culture; virtual shopping

\begin{abstract}
The convenience of the network develops a set of network shopping; sellers sell marketing products through net site that is very common. Before the emergence of the network, the electronic data communication has been adopted by some enterprises as a business approach, but the scope of application is limited, and there are many security issues. The rapid development of the network makes various new business models become possible. With the increment of network usage, the network is playing an increasingly important role in modern life. This article explores the impact of the market about online business.

With the popularity of the network, the development of e-commerce is more and more mature, a variety of emerging e-commerce business models have also emerged. In recent years, group buying evolved into a business model on the site, consumers can buy goods at preferential prices, which can get discounts, save cost, while the sellers make puerile. The group buying net site company extracts the commission from the seller, and the amount of the commission may depend on the bargaining power of the manufacturers themselves, that is to say, it is the store's own visibility. Group buying has set off a boom, but also it brings another marketing strategy for manufacturers.
\end{abstract}

\section{The summary of network group buying}

\section{The concept of group buying}

Group buying is an activity that makes the use of a large number of consumer demand, the manufacturers bargaining, requires a higher discount or other benefits. Network group buying is the main consumers have the same needs of a set of goods or services in the network platform, in order to lower the price, saving monetary or other related interests.

\section{The model of group buying}

There are two group buying modes. One is initiated by the consumer. Consumers raise the majority of users through the entity or the network, contact their own business to get the lower freight, enjoy low discounts, and take free gifts and other promotions. The other is that making online group buying site as Communication Bridge between business supplier and consumer.That is, group buying consumers play the role of intermediary business, convey preferential information and provide the opportunity to buy goods through the network platform, consumers make group buying through the group buying site, and consumers do not need to convene.

\section{The factors that affect the development of group buying}

\section{Region}

Restaurants accounted for the highest proportion in the current sale types of group buying. However, such goods are most likely to be affected by geographical boundaries, because consumer is more concerned about the convenience of the region in the buy behavior compared with the price.

\section{Low threshold}

The threshold of group buying market is not high, practitioners hope to break through the fierce environment, obtain a leading position. At first, most practitioners imitate the pioneers of the market, 
expect into the profit stage at the fastest speed. But when the market from the embryonic period to the growth period, it will begin to appear out of the mechanism. So practitioners have begun to adjust their business strategy in the direction of differentiation. In terms of group buying market, the current practitioners are still inclined to develop by the product, for example, they can sell goods alone.

\section{Trade alliance}

In order to improve the competitiveness of the market, practitioners through make cooperation with different industries to achieve this goal. For example, group buying practitioners make cooperation with the magazine to increase the site's exposure, at the same time it also can attract different customers.

\section{Loyalty}

How to make customers willing to carry out the second consumer behavior for group buying business practitioners is a challenge. In the group buying purchase mode of consumption, the customer is very easy to invest in another online shopping site because of the price of incentives. Therefore, to break this one-time consumption model is a very important subject of practitioners.

\section{Vertical market}

When practitioners consider the differentiated business strategy,,they begin to think from the traditional level of thinking to the vertical market development,in order to strengthen the consumer dependence on the network group buying behavior. Vertical group buying site features that it can be targeted for specific customer groups to launch goods, which not only allow practitioners more accurate positioning of the consumer groups, while improving service quality and easier to import products into the purchase site.

\section{The market impact on the network group buying}

In the late 1990s, the network completely changed the survival and competition of enterprises environment at the overwhelming trend, which has completely changed the industrial structure and rules of the game.

In this wave of competition, more and more consumers use the network to shop, on the other hand, the Internet Company level the consumer's expectations and autonomy in order to compete in the market, regardless of cost competition. The traditional business model seems to have disintegrated in the past over the past few decades, especially in the financial market, money-losing network companies publicly listed, let shareholders in a short time to obtain considerable capital interests, the network has undoubtedly completely changed the survival and competition of enterprises in the environment, and it made wealth reallocation in the process of value transfer.

The network not only blurred the industry line, but also increased the blurring of customers, suppliers, competitors, complementary and business boundaries. Business operators are facing a new corporate revolution, they hope that through competitive cooperation develop effective new business model, which is a revolutionary rules of the game.

Combined with traditional market and network group buying business model is undoubtedly a new solution. It has the network world virtual equality and credibility of the transfer of the characteristics, and this solution is whether effective, in addition to the combination of tangible resources, how to make the combination of the strength, the relationship and the learning ability is the key to the mutual promotion between the virtual market and the physical market.

The network should not only connect with the market of the enterprise, but also with the business design, which defines the enterprise market by a complete solution, convey the value of customers by the use of experience and relationship. Business managers are the most difficult and the most important task is to quickly and correctly let the business strategy, organization, talent, processes and application systems match each other in order to enjoy the creative fruit. 


\section{The problems of network group buying}

\section{The problem between online group buying business and the manufacturers relationship.}

Network group buying business and manufacturers are generally using the telephone or network contact discount prices and sales of goods, after the negotiations they determine the coworker-relationship, and then the network group buying business send personnel to take photos, as well as to publish discount goods and make limited time sales. This kind of negotiation is more casual, the evaluation criterion is low, this understanding of the product is not comprehensive, and resulting in sales is not high.

Network group buying business with manufacturers before discussing the formal cooperation, they should first understand the degree of understanding of the manufacturers for the purchase model, and what is worth recommending products inshop which can plan the best buy marketing. In the choice of the store, it is not casual to find a shop to talk about, we must first from the major evaluation sites ,choose good service, good reputation of the store, we finally decide whether to do cooperate proposals after the basic research work. Second, the group buying site also need to hire a number of special photographers to take photos, the planning department make planning page layout, and write the copy of the goods, and then schedule the shelves. Customer service is a window to connect consumers and stores to ensure smooth communication between the two sides. A set of standard assessment of the network group buyers to build a brand image is very important; the network group buyers' credit evaluation is the bridge between consumers and business, which can reduce the cognitive risk. In general, manufacturers must pay a certain marketing costs to the network group buyers. Manufacturers give a certain percentage of the network buy site sales of goods sales as intermediary fees to the network group buyers. As the network group buying site sell discount products, the profits of product itself are lower, if the sales are relatively small, it is easy to make a loss of business, it has no profit at all.

\section{The extension of the problem to consumers that manufacturers use the network to sell products.}

The extension of the problems are as follows: when consumers use group discount coupons, they find that the goods and the expected are different, such as the existence of time restrictions on goods, restrictions on the use of goods, goods have a daily limited number of copies, merchandise photos and the actual does not match, the goods service quality is decline. Therefore, when the site sale these goods, in addition to indicate the use of cut-off time, merchandise features, the use of coupons and the need for prior appointment and other elements, but also it is a good faith to remind consumers to buy goods through the network group buying site be careful.

\section{Suggestions on the Development of Network group buying}

Group buying site should make better preparation work of manpower and material. For the catering industry as example, because in the restaurant group buying site, there will be large-scale traffic from time to time, group buying site should make better preparation work of manpower and material in order to avoid the influx of guests, the staff rush.

Group buying site can mark detailed information. This information includes the size of the store, group buying time, group buying consumer requirements, such as booking and other information. Businessmen would rather refuse to guests in advance, they do not let the guests disappointed, if the guests cannot make a reservation, and you should do the relevant mark. The next time the customer patronizes, the store should give the priority arrangements. This can be closer to the relationship with the guests, to obtain the trust of the guests.

The store can prepare some drinks and snacks for guests.If guests stay for a long time, you can prepare some drinks and snacks for guests. Although these small tricks spend some small cost, but compared to the loss of these guests, this small cost does not matter, many guests will be willing to wait for these snacks to give more patience. 


\section{In conclusion}

Group buying is that the manufacturers rely on the network to sell products, manufacturers and network group buyers in the signing of the contract should be carefully assessed whether the two sides can achieve a win-win objective. The relationship between manufacturers and network group buying business is mutually beneficial symbiosis; manufacturers should maintain their own product quality, shipments and customer service quality, which can attract more guests. If consumers can carefully select this group buying site, they can greatly avoid the risk of injury. Therefore, if you select the group buying site, please protect your own interests so as not to be deceived.

\section{References}

[1]Li Chen-huan; buy mode game analysis [J]; Journal of Guangdong Vocational College of Finance and Economics; 200602

[2]Huang Jun; Xing Yang; network buy trade model [J]; price theory and practice; 201104

[3]Zhou Xiaoyong; Wu Yuping; e-commerce model of network buy [J]; Science and Technology Information; 201020

[4] Qi Wen; network group purchase business model research: based on Groupon [J]; human resources management; 201010 